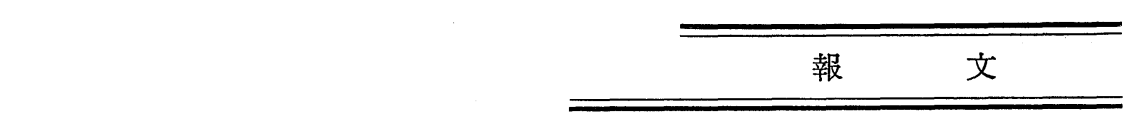

\title{
Gluten 代替タン白質の検索に関する研究
}

（第 5 報）大豆 $11 \mathrm{~S}$ グロブリンへの製パン性の付与

山本 淳*・西岡ゆかり*

\begin{abstract}
Studies of a Searching Examination for Gluten Replace Protein
\end{abstract}
Part V Improvement of Bread Baking Properties in Soy 11S Globlin

Atsushi YAMAMOTO** and Yukari NishioKA**

Summary

In the searching examinations for gluten replace proteins through bread baking with non-glutinous rice flour and various proteinaceous substances, soy $11 \mathrm{~S}$ globlin hindered remarkably the bread baking properties of wheat gluten. However, soy $11 \mathrm{~S}$ globlin had changed drastically by adding of $4 \%$ egg yolk powder ${ }^{1)}$. It is well known that lecithin is the main component of polarlipid in egg yolk and soy beans. Therefore, the changes of bread baking properties in soy $11 \mathrm{~S}$ globlin by adding of lecithin produced from egg yolk or soy beans were examined.

In these experiments, added $0.05 \%$ egg lecithin converted remarkably the bread baking properties of soy $11 \mathrm{~S}$ globlin, and soy lecithin gave the similar results. Moreover, it was elucidated that soy 11S globlin was altered to show the excellent bread baking properties by adding of $0.5 \%$ sodium dodecyl sulfate (S.D.S.) or glycerol monostearate (Monoglyceride). Consequently, it was presumed that the tight intramolecular hydrophobicity of soy $11 \mathrm{~S}$ globlin was loosened by absorption of such surfactant substances, then, soy $11 \mathrm{~S}$ globlin obtained the flexibility to response with the mixing stress during dough making processes.

\section{緒 論}

米粉を主体としたパンの焼成に際し, 小麦グルテンと

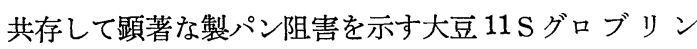
が，混捏ドウの凍結保蔵によって明らかに製パン性の向 上がみられ，さらに，少量の卵黄粉末の添加によって一 転して優れた製パン性発現に転ずることを見出し，既に 報告')した。

一方，大豆種子，卵黄中には共に燐脂質であるレシチ

*帝国女子大学家政学部 (甬570 大阪府守口市藤田町6-173)

**Teikoku Women's University, Department of Domestic Science (6-173, Tohdacho, Moriguchishi, Osaka 570, JAPAN)
ン (Phosphatidyl Cholin Glycerid) の存在が早くから 知られており, 大豆レシチン, 卵黄レシチンのいずれも 食品, 医薬の分野で乳化剤として広く用いられている。 Adler および Pomeranz 2) は小麦粉パンの焼成に際し大 豆粉を添加して Loaf 容積に及ぼす影響を験した際, 酸 化剂と併せて大豆レシチンの添加が Loaf 容積の減少を 防止するのに効果があることを見出し，また，Mizrahi 等 ${ }^{3)}$ は分離大豆タン白質でも同様に小麦粉パンへの添加 に際し, レシチンの併用が焼成容量の減少を防止できる ことを報告している。これらのことから，前の卵黄粉末 の添加による11S グロブリンの製パン性発現が，卵黄中 に含まれるレシチンによる可能性が大きいものと考え， 


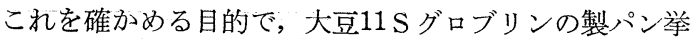
動に対する卵黄ならびに大豆レシチンの添加効果を験し た。これと共に, レシチンの作用機作を明らかにする目 的で, 球状タン白質の可溶化の機作が明らかにされてい る S.D.S. (Sodium Dodecyl Sulfate), 乳化牏として 広く用いられるモノグリセリド（Glycerol Monostearate）の添加効果をも併せて験した。以下，これらの 結果を報告する。

\section{実 験 の 部}

\section{1. 実験 材 料}

（1）大豆11Sグロブリン：前報 ${ }^{1)} に$ 記載した方法によ り調製した。すなわち，長谷川らの ${ }^{4}$ 記述に従い，柴崎

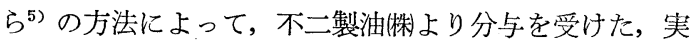
験用に調製された低温脱脂大粉を20倍量の0.03Mトリス 緩衝液 ( $\mathrm{pH}$ 8.0) で抽出し, 可溶性区分から $\mathrm{pH} \quad 6.2$ で沈でんする画分を遠心捕集, 透析後凍結乾燥して, 以 下の実験に供した。

（2）レシチン；S.D.S.； モノグリセリド：大豆レシ チン, 卵黄レシチン, モノグリセリドはいずれも和光純 薬製の試薬を, また, S. D.S. は同社の電気泳動用試薬 を購入，使用に供した。

（3）製パン材料：米粉 (日本製粉㫼：免月 A32), 粉 末小麦グルテン（H.P.P.社，オーストラリア）の主要 原料ならびにその他の副資材は総て前報 ${ }^{6)}$ に準じて実験 に供した。

\section{2. 実験 方法}

（1）大豆11S グロブリン添加パンの焼成 : 米粉80\%，

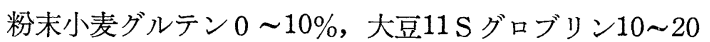
\%の組成について，11S グロブリンの0.05〜1.00\%とな るようにレシチン, S.D.S., モノグリセリドのいずれか を添加し，広く行われている小麦粉食パンの焼成に準じ てパンを焼成した。これらの手法は総て前法 ${ }^{6}$ と同様に 行った。

なお，製パンに先立って，各種添加物の所定量を添加 した11Sグロブリンを 5 倍量の $3 \%$ 食塩水と自動乳 鉢 中，室温で30分間擂潰，ゲル化してドウの調製に加えた もの，無擂潰でドウ調製を行ったもの，また，これらの 混捏ドウをー $5{ }^{\circ} \mathrm{C} ， 14$ 日間凍結保蔵した後, 所定の発酵 過程を経て焼成したもの，無凍結のまま焼成したものの 比較は総て前報 ${ }^{1)}$ と同様に行った。

焼成パンの評価に際し，今回の実験では主原料の組成
比, 発酵, 焼成の手順の総てが同一条件に従って行った ので, 評価の基準に焼成容量を直接比較することに重点 を置いた。スライス面のスポンジ形成の状態, また, 焼 成パンの比容積值 (S. V. 值) を評価することは従前通 りである。

（2）各種添加物による11S グロブリンの変化の追跡 : 前報 ${ }^{6)}$ と同様, 調製ドウに20倍量の $\mathrm{M} / 1^{-}$燐酸緩衝液 (pH 7.6) を加えて冷室中 1 夜振盪抽出して溶出する タン白質を S.D.S.-PAGE (Polyacrylamide Gel Electrophoresis）により変化の有無を験した。

\section{結果ならびに考察}

\section{1. レシチンの添加による大豆11S グロブリンの}

\section{製パン性の変化}

$11 \mathrm{~S}$ グロブリンの0.05，0.10，0.50，1.00\%の卵黄ま

Table 1 Changes of Bread Baking Properties in Soy 11S Globlin affected by Adding of Lecithin

\begin{tabular}{|c|c|c|c|c|c|c|}
\hline Kind of & & & & & & S.V. \\
\hline Lecithin & $\begin{array}{l}\text { ratio } \\
(\%)\end{array}$ & $\begin{array}{l}\text { grind } \\
\text { (min) }\end{array}$ & $\begin{array}{c}\text { freeze } \\
\left({ }^{\circ} \mathrm{C} \text {, day }\right)\end{array}$ & $\begin{array}{l}\text { volume } \\
(\mathrm{ml})\end{array}$ & $\begin{array}{l}\text { weight } \\
\text { (g) }\end{array}$ & value \\
\hline Egg Lecithin & 0.05 & - & - & 342 & 133.0 & 2.6 \\
\hline & & 30 & - & 392 & 137.6 & 2.8 \\
\hline & & 30 & $-5,14$ & 227 & 118.8 & 1.9 \\
\hline & 0.10 & - & - & 260 & 111.0 & 2.3 \\
\hline & & 30 & - & 327 & 141.4 & 2.3 \\
\hline & & 30 & $-5,14$ & 367 & 123.4 & 3.0 \\
\hline & 0.50 & - & - & 188 & 110.0 & 1.7 \\
\hline & & 30 & - & 300 & 145.4 & 2.1 \\
\hline & & 30 & $-5,14$ & 270 & 118.9 & 2.3 \\
\hline & 1.00 & - & - & 210 & 107.8 & 1.9 \\
\hline & & 30 & - & 307 & 138.9 & 2.2 \\
\hline & & 30 & $-5,14$ & 290 & 121.2 & 2.4 \\
\hline Soy Lecithin & 0.05 & - & - & 300 & 107.8 & 2.7 \\
\hline & & 30 & - & 300 & 118.0 & 2.5 \\
\hline & & 30 & $-5,14$ & 193 & 128.6 & 1.5 \\
\hline & 0.10 & - & - & 260 & 130.0 & 2.0 \\
\hline & & 30 & - & 320 & 112.1 & 2.9 \\
\hline & & 30 & $-5,14$ & 173 & 120.5 & 1.4 \\
\hline & 0.50 & - & - & 312 & 139.0 & 2.2 \\
\hline & & 30 & - & 309 & 140.4 & 2.2 \\
\hline & & 30 & $-5,14$ & 245 & 100.8 & 2.4 \\
\hline & 1.00 & - & - & 281 & 138.0 & 2.0 \\
\hline & & 30 & - & 290 & 135.2 & 2.1 \\
\hline & & 30 & $-5,14$ & 260 & 120.2 & 2.2 \\
\hline No Ingredient & & 30 & - & 147 & 144.0 & 1.0 \\
\hline & & 30 & $-5,14$ & 216 & 142.2 & 1.5 \\
\hline Egg Yolk & 4.0 & 30 & 一 & 385 & 149.6 & 2.6 \\
\hline & & 30 & $-5,14$ & 296 & 119.2 & 2.5 \\
\hline
\end{tabular}


たは大豆レシチンの添加, ドウ形成に先立って行った加 塩擂潰, 混揘ドウの凍結保蔵の有無の夫々について得ら れた製パン試験の結果を取りまとめて Table 1 亿示す。

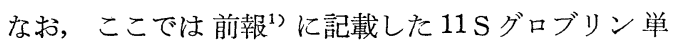
独, ならびに, 卵黄粉末 $4 \%$ を添加した焼成パンの結果 をも併せて記載した。これらの結果から，11 S グロブリ ン単独添加を除いて, いずれも擂潰, 無凍結で得た焼成 パンのプロファイルを取りまとめて Fig. 1 に示した。

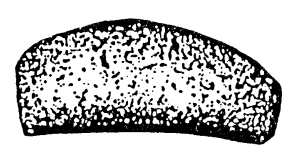

No Ingrediend grind and foeeze Baked Volume $216 \mathrm{~m} l$

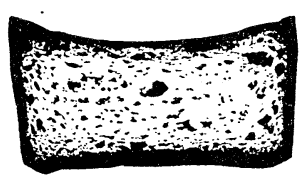

Egg Lecithin 0.05\% grind and no-freeze Baked Volume $392 \mathrm{ml}$

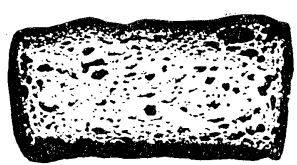

S.D.S. $\quad 0.50 \%$ grind and no-freeze Baked Volume $350 \mathrm{~m} l$

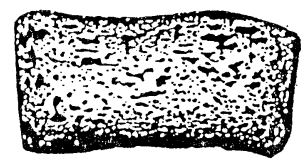

Egg Yolk $4 \%$ grind and no-freeze Baked Volume $385 \mathrm{~m} l$

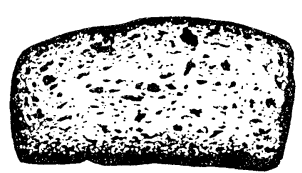

Soy Lecithin $0.10 \%$ grind and no-freeze Baked Volum $320 \mathrm{~m} l$

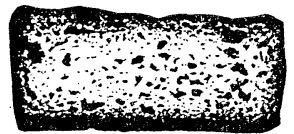

Mono-glyceride $0.50 \%$ grind and no-freeze Baked Volume $347 \mathrm{~m} l$

Basal Constitution of Dough: non-glutinous rice flour $\quad 80 \%$ wheat gluten powder $\quad 10$ freeze dried soy $11 \mathrm{~S}$ globin 10

Fig. 1 Profiles of Baked Goods improved Baking Properties in Soy 11S Globlin by Various Conditionings

これらの結果, 卵黄レシチン, 大豆レシチン共に, 加 塩擂潰, 無凍結区が共通して良い結果を示した。そし て, 前報1) で得られた卵黄粉末 $4 \%$ 添加 $11 \mathrm{~S}$ グロブリン の擂潰, 無凍結ドウの焼成容量が $385 \mathrm{~m} l$ ，比容積 2.6 で あったのに対して, 今回の卵黄レシチン $0.05 \%$ 添加, 擂 潰, 無凍結ドウの焼成容量は $392 \mathrm{~m} l$, 比容積 2.8 を示し た。このことは，そのままでは極めて顕著な製パン阻害 を示す大豆 $11 \mathrm{~S}$ グロブリンが，僅か $0.05 \%$ の卵黄レシチ ンの添加によって，一転して優れた製パン性発現に変っ たことを示すもので, 前の卵黄粉末添加による11S グロ
ブリンの製パン性の変化が，卵黄中に15 20\%含有され るレシチンに起因したとして間違いあるまい。

実験に供した卵黄レシチンと大豆レシチンの間では, それぞれの最適添加量, 製パン性改良の効果に多少の差 が見られるが，両者共に11S グロブリンに働いて，その 製パン阻害を一転して優れた製パン性発現に転化させる ことが明らかとなった。Phosphatidyl Chrlin を親水性 残基として, 非極性長銷脂肪酸鎖を構成要素とするレシ チンの作用機作は, 12 個のサブユニットが相互に -S.S架橋で結ばれ, 強固に結合した巨大球状タン白質である 大豆 $11 \mathrm{~S}$ グロブリンの内部疎水結合域に配位する長銷状 脂肪酸残基と, 表面に露呈する親水性の Phosphatidyl Cholin 残基の配位結合によって $11 \mathrm{~S}$ グロブリンの内部 疎水結合を緩解し，11 S グロブリンの強い球状保持性に ゆるみを与えた結果として良いのではあるまいか。

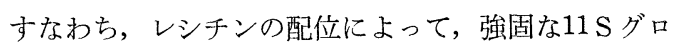
ブリンの内部蹯水結合にゆるみを生じ, 柔軟性が付与さ れた結果, 混捏などの外力によって小麦グルテンと類似 した構造変化を可能にし，これが11 S グロブリンの製パ ン性を大きく変化させた原因として良さそうである。

2. S.D.S., モノグリセリド添加による大豆 11S ダ ロブリンの製パン性の変化

S.D.S. が球状タン白質内部の疎水性部分に非極性の 炭化水素長鎖を配位し, 表面に強い極性を示すスルフォ ン酸ナトリウム残基を露呈して球状タン白質を広く水溶 性にすると共に，アクリルアミドゲル中を陽極に向って タン白質を泳動させる基本要素となっていることは良く 知られた事実である。非極性残基をタン白質内部に，極 性基を表面に配位する S.D.S.の作用機作は，前節で推 定した $11 \mathrm{~S}$ グロブリンに対するレシチンの作用機作と頗 る類似するものである。

すなわち，レシチンの添加による11S グロブリンの製 パン性の変化がレシチンの配位による内部蹯水結合の緩 解によるものとすれば，同様の効果が S.D.S. 或はモ， グリセライドなどの表面活性物質の添加によっても見ら れる䈏である。これを確かめる目的で, S.D.S., モノグ リセライドの $0.05 \sim 1.00 \%$ を添加した時の $11 \mathrm{~S}$ グロブリ ンの製パン性の変化を取りまとめて Table 2 に示す。

また，S.D.S. モノグリセライドの0.50\%を添加，擂 潰, 無凍結ドウの焼成結果は前の Fig. 1 に併わせて示 した。

これらの結果は予期した通り S.D.S., モノグリセラ 
Table 2 Changes of Bread Baking Properties in Soy 11 S Globlin affected by Adding of Surfactant

\begin{tabular}{|c|c|c|c|c|c|c|}
\hline \multirow{3}{*}{$\begin{array}{l}\text { Kind of } \\
\text { Surfactant } \\
\text { S.D.S.* }\end{array}$} & \multirow{3}{*}{$\begin{array}{c}\text { Added } \\
\text { ratio } \\
(\%) \\
0.05\end{array}$} & \multirow{2}{*}{\multicolumn{2}{|c|}{$\frac{\text { Conditioning }}{\text { grind freeze }}$}} & \multicolumn{2}{|c|}{ Baked } & \multirow{2}{*}{$\begin{array}{l}\text { S.V. } \\
\text { value }\end{array}$} \\
\hline & & & & $\begin{array}{l}\text { volum } \\
(\mathrm{m} l)\end{array}$ & $\begin{array}{c}\text { weight } \\
\text { (g) }\end{array}$ & \\
\hline & & 30 & - & 227 & 144.2 & 1.6 \\
\hline & & 30 & $-5,14$ & 241 & 114.5 & 2.1 \\
\hline & 0.10 & 30 & - & 288 & 152.0 & 1.9 \\
\hline & & 30 & $-5,14$ & 233 & 108.9 & 2.1 \\
\hline & 0.50 & - & - & 328 & 138.4 & 2.4 \\
\hline & & 30 & - & 350 & 138.2 & 2.5 \\
\hline & & 30 & $-5,14$ & 294 & 116.0 & 2.5 \\
\hline & 1.00 & 30 & - & 305 & 151.4 & 2.0 \\
\hline & & 30 & $-5,14$ & 277 & 135.2 & 2.0 \\
\hline \multirow[t]{7}{*}{$\begin{array}{l}\text { Monogly- } \\
\text { ceride** }\end{array}$} & 0.10 & 30 & - & 220 & 134.3 & 1.6 \\
\hline & & 30 & $-5,14$ & 298 & 134.2 & 2.2 \\
\hline & 0.50 & - & - & 347 & 132.5 & 2.6 \\
\hline & & 30 & - & 290 & 136.6 & 2.1 \\
\hline & & 30 & $-5,14$ & 247 & 82.5 & 3.0 \\
\hline & 1.00 & 30 & - & 206 & 144.4 & 1.4 \\
\hline & & 30 & $-5,14$ & 321 & 125.3 & 2.7 \\
\hline
\end{tabular}

*Sodium Dodecyl Sulfate

**Glycerol Monostearate

イド共に11Sグロブリンの製パン性付与に大きく効果を 示したことが明らかになった。そして, 前節で推定した $11 \mathrm{~S}$ グロブリンの内部柾水結合の緩解が製パン性発現を 起因するとした推定を強く裏付ける結果となった。

\section{3. 各種添加物による大豆11S グロブリンの変化の} 追跡

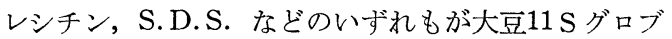
リンの強固な球状構造に変化を与えるものとして, その 製パン性の発現を捉えたが，これらの変化が単に球状構 造の内部疎水結合の緩解にのみ関与したものか, 或はこ れらの添加物によって11S グロブリンに Aggregation, 反対に Degradation などの変化が起っていないかどら かを確かめる必要がある。このため, 卵黄, 大豆レシチ ン, S.D.S., モノグリセライドの各 $0.5 \%$ 添加ドウから $\mathrm{M} / 15$ - 燐酸緩衝液（pH 7.6）で抽出した可溶性区分に ついて, S.D.S. -PAGE (Polyacrylamide Gel Electrophoresis）によって，それぞれの泳動ゲルを無添加ドウ から得たものと比較した。これらの結果を Fig. 2 に示 す。

これらの結果，いずれの抽出区分についても11S グロ ブリン構成バンド以外の新しいバンドの出現は認められ ず, レシチン, S.D.S., モノグリセライドなどの表面活

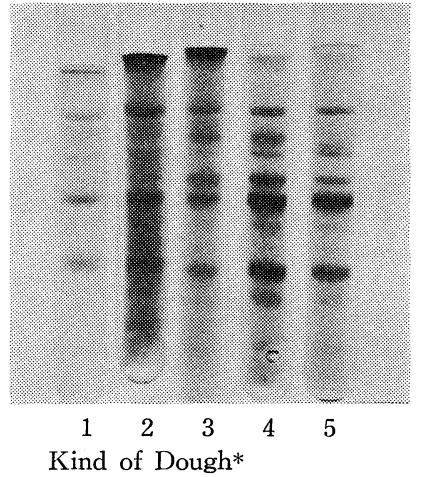

Gel

No.

1 Soy $11 \mathrm{~S}$ Globlin+no-ingredient

\begin{tabular}{|c|c|c|}
\hline "I & egg lecithin & $0.50 \%$ \\
\hline "I & soy lecithin & 0,50 \\
\hline$\prime \prime$ & S.D.S. & 0.50 \\
\hline "I & mono-glyceride & 0.50 \\
\hline
\end{tabular}

*Through-out the respective dough, soy $11 \mathrm{~S}$ globlin was grinded with or without ingredient, then added for dough prapartion

Fig. 2 Changes of S.D.S.-P.A.G.E. affected by Adding of Surfactant in Soy 11S Globin

性物質の添加によって，11S グロブリン構成タン白質間 で新たな会重合成は分解などが起っていないことは明ら かである。このことからも，表面活性物質の添加による

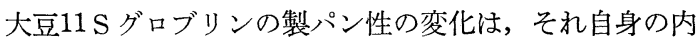
部変化に基くものであることを強く示唆するものと申し て良いであろら。

\section{4. 米粉, 大豆11Sグロブリンパンの焼成}

小麦グルテンと共存して，そのままでは顕著な製パン

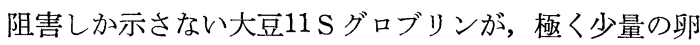
黄或は大豆レシチンの添加によって，一転して優れた製 パン性発現に転ずることを知ったが，これらの結果に基 いて，米パン燒成の基本組成で小麦グルテンを大豆 $11 \mathrm{~S}$ グロブリンに置換してパンを焼成した。これらの結果を Table 3 および Fig. 3 に示す。

Table 3 Changes of Baking Properties in Rice Breads altered Constituting Ratio of Wheat Gluten and Soylls Globlin containing $0.10 \%$ Egg Lecithin

Soy 11S Wheat Conditioning Baked* S.V. globlin gluten grind freeze volume weight value (\%) (\%) (min) $\left({ }^{\circ} \mathrm{C}\right.$, day) $(\mathrm{ml}) \quad(\mathrm{g})$

$\begin{array}{lllllll}10 & 10 & 30 & - & 327 & 141.4 & 2.3\end{array}$

$\begin{array}{lllllll}15 & 5 & 30 & - & 349 & 133.5 & 2.6\end{array}$

$\begin{array}{lllllll}20 & - & 30 & - & 341 & 131.4 & 2.6\end{array}$

* Baked goods were composed commonly with nonglutinous rice flour $80 \%$, proteinaceous substance $20 \%$, added water $80 \%$ and egg lecithin $0.10 \%$ 


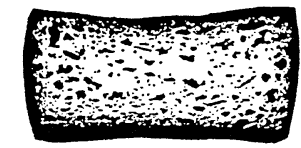

Wheat Gluten Soy 11S Globlin +

$0.1 \%$ Egg Lecithin 10

Baked Volume $\quad 327 \mathrm{~m} l$

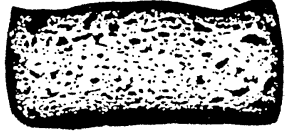

$5 \%$

15

$349 \mathrm{~m} l$
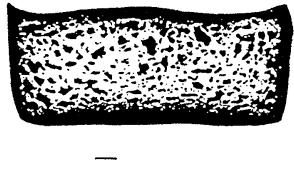

$20 \%$

$341 \mathrm{~m} l$

Fig. 3 Profiles of Baked Goods decreased Wheat Gluten to replace with Soy $11 \mathrm{~S}$ Globin containing $0.1 \%$ Egg Lecithin

小麦グルテンを $5 \%$, 無添加に減らし, その代りに大 豆 $11 \mathrm{~S}$ グロブリンを $15 \%, 20 \%$ 添加し，卵黄レシチンを $0.1 \%$ 加えて焼成したパンでは小麦グルテンの有無に拘 らず，焼成容量, S.V. 值ともに却て優れた結果を示し, 内部スポンジ形成も満足すべきものであった。米粉と大 豆11 S グロブリンを主要構成要素として立派にパンが焼 けたのである。知る限りにおいて，他に類例を見ない結 果と申して差支えない。

\section{総括ならびに要約}

\section{以上を総括して要約すると}

(1)米粉を主体としたパンの焼成に際して，小麦グルテン

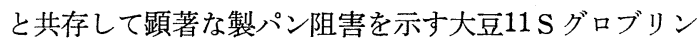
が，少量の卵黄粉末の添加によって一挙に優れた製パン 性の発現に転ずることから，卵黄中にあって，既に大豆 粉あるいは大豆タン白質の製パン性の向上に効果が認め られているレシチンについて，大豆 $11 \mathrm{~S}$ グロブリンの製 パン性に及ぼす影響を験した。

(2)卵黄ならびに大豆レシチンの何れかを11S グロブリン の0.05，0.10，0.50，1.00\%になるように添加し，予め 加塩擂潰した後ドウ形成, 発酵の過程を経て焼成する と, レシチンの種類および添加量によって多少の変動は 見られるが，いずれも優れた米パンが焼成できた。

(3)このような, レシチンの添加による大豆 $11 \mathrm{~S}$ グロブ リンの製パン機能の発現は, レシチンの非極性脂肪酸側 鎖を $11 \mathrm{~S}$ グロブリンの内部疎水部分に，また，親水性の Phosphatidyl Cholin 残基をグロブリン表面に配位し， 強固な内部疎水性を緩解することによって起るものと推 定した。

(4)レシチンによる11S グロブリンの製パン性発現が強 固な内部疎水結合の緩解によるものであれば，当然， S.D.S. 或はモノグリセリドなどの表面活性物質によっ
ても同様の効果が期待できるものとして, S.D.S., モノ グリセリドについても少量を $11 \mathrm{~S}$ グロブリンに添加して パンを焼成した結果, 添加量或は効果に多少の差はみら

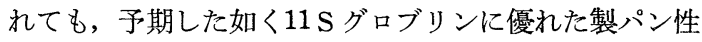
を付与することができた。

(5)これらの添加物による11S グロブリンの変化を検す る目的で, 混担ドウを燐酸緩解液 ( $\mathrm{pH}$ 7.6) と振湯し,

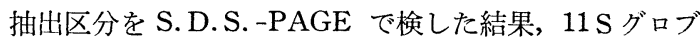
リンの構成タン白質以外のバンドの出現は認められず, これらの添加によって11S グロブリンに会重合，解裂な どが起っていないことが確かめられた。

(6)これらの結果に基き，米パン基本組成から小麦グル

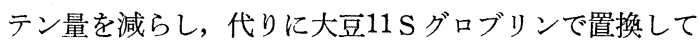

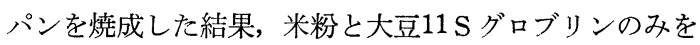
基本組成とするパンが焼成できた。

本研究の概要は昭和59年度日本農芸化学会大会におい て報告した。研究を行らに当って帝国学園研究奨励金の 交付を受けた。物心両面にわたって援助を賜わった協和 酺酵工業㑣，快く実験試料を供与いだいた不二製油㑣， 実験に協力頂いた越賀春名, 白田洋子, 高田千鶴子の皆 さんに厚く謝意を表する。

\section{引用文 献}

1) 山本 淳・西岡佀かり：本誌，10,48 (1984)

2) L.Adler and Y.Pomeranz: J.Sci. Food Agr., 10, 449 (1959)

3) S.Mizrahi et al.: Cereal Chem. 44, 193 (1967)

4）長谷川喜代三他：農化誌，53，375 (1979)

5) V.H.THANK and K.Shibasaki: J.Agr. Food Chem., 26, 692 (1978)

6) 山本 淳: 本誌, 8,76 (1982) 